\title{
Resveratrol ameliorates nutritional steatohepatitis through the mmu-miR-599/PXR pathway
}

\author{
LINGBO KONG, XINYU AN, LINGXI HU, SIYU ZHANG，LINGDI LIU, \\ SUXIAN ZHAO, RONGQI WANG and YUEMIN NAN \\ Department of Traditional and Western Medical Hepatology, \\ Third Hospital of Hebei Medical University, Shijiazhuang, Hebei 050051, P.R. China
}

Received August 20, 2021; Accepted December 22, 2021

DOI: $10.3892 /$ ijmm.2022.5102

\begin{abstract}
The aim of the present study was to elucidate the effect of resveratrol on non-alcoholic steatohepatitis (NASH), and the molecular basis in mice and Hepa1-6 cells, in order to verify its therapeutic effect. C57BL/6J mice were fed a methionine-choline-deficient (MCD) diet to induce steatohepatitis and were treated with resveratrol. Mouse sera were collected for biochemical analysis and enzyme-linked immunosorbent assay, and livers were obtained for histological observation, and mmu-microRNA (miR)-599 and inflammation-related gene expression analysis. Hepa1-6 cells were treated with palmitic acid to establish a NASH cell model, and were then treated with resveratrol, or transfected with mmu-miR-599 mimic, mmu-miR-599 inhibitor or recombinant pregnane $\mathrm{X}$ receptor (PXR) plasmid. Subsequently, the cells were collected for mmu-miR-599 and inflammation-related gene expression analysis. Reverse transcription-quantitative polymerase chain reaction and western blotting were used to assess mmu-miR-599 expression levels, and the mRNA and protein expression levels of PXR and inflammation-related genes. The binding site of mmu-miR-599 in the PXR mRNA was verified by the luciferase activity assay. Mice fed an MCD diet for 4 weeks exhibited steatosis, focal necrosis and inflammatory infiltration in the liver. Resveratrol significantly reduced serum aminotransferase and malondialdehyde levels, and ameliorated hepatic injury. These effects were associated with reduced mmu-miR-599 expression, enhanced PXR expression, and downregulated levels of nuclear factor- $\kappa \mathrm{B}$, tumour necrosis factor- $\alpha$, interleukin (IL)-1 $\beta$, IL-6, NOD-like receptor family pyrin domain-containing protein 3 and signal transducer and activator of transcription 3. Administration of the
\end{abstract}

Correspondence to: Dr Rongqi Wang or Dr Yuemin Nan, Department of Traditional and Western Medical Hepatology, Third Hospital of Hebei Medical University, 102 You Yi Street, Shijiazhuang, Hebei 050051, P.R. China

E-mail: wangrongqiw@163.com

E-mail: nanyuemin@163.com

Key words: non-alcoholic steatohepatitis, resveratrol, mmu-miR-599, pregnane $\mathrm{X}$ receptor
mmu-miR-599 mimic inhibited PXR expression in Hepa1-6 cells, whereas the mmu-miR-599 inhibitor exerted the opposite effect. A binding site for mmu-miR-599 was identified in the PXR mRNA sequence. Furthermore, overexpression of PXR inhibited the expression of inflammatory factors in Hepa1-6 cells. The present study provided evidence for the protective role of resveratrol in ameliorating steatohepatitis through regulating the mmu-miR-599/PXR pathway and the consequent suppression of related inflammatory factors. Resveratrol may serve as a potential candidate for steatohepatitis management.

\section{Introduction}

Non-alcoholic steatohepatitis (NASH) is the severe stage of non-alcoholic fatty liver disease (NAFLD), which may progress further to cirrhosis and even hepatocellular carcinoma $(1,2)$. The management of NASH is based on lifestyle changes, with a focus on reducing body weight through physical exercise and adherence to a healthy diet (3), which are hard to sustain. There is currently no effective pharmacological treatment for NASH. Bioactive food constituents are considered potential treatment approaches for NASH. Resveratrol is a natural polyphenol; it is a phytoalexin that is synthesized by a number of plants in response to damage, and can be found in grapes, berries, legumes, peanuts, tea and wine, although in the low milligram range (4). In a clinical trial of patients with NAFLD, daily administration of $500 \mathrm{mg}$ resveratrol for 12 weeks significantly improved anthropometric parameters and liver injury, and decreased inflammatory markers (5). Resveratrol has shown promising antisteatotic, antioxidant and anti-inflammatory effects in NASH (6); however, the detailed mechanism has not been fully clarified.

MicroRNAs (miRNAs/miRs) are small, endogenous, noncoding RNAs that interact with the 3'-untranslated regions (UTRs) of target mRNA, resulting in the inhibition of translation or the promotion of mRNA degradation (7). miRNAs have been shown to be involved in the development of NAFLD $(8,9)$. miR-599 has been reported to promote the apoptosis of papillary thyroid carcinoma cells, and to promote interleukin (IL)-1 $\beta$-induced chondrocyte apoptosis and inflammation in osteoarthritis $(10,11)$. Hepatocyte apoptosis and the inflammatory response are important pathological processes in NASH that cause hepatocyte death and liver damage, promoting disease progression (12). However, 
to the best of our knowledge, whether miR-599 is involved in the development of NASH remains to be determined.

Pregnane $\mathrm{X}$ receptor (PXR) is a liver-enriched xenobiotic-responsive transcription factor that exerts anti-inflammatory effects; treatment with the PXR agonist pregnenolone $16 \alpha$-carbonitrile has been reported to suppress the increased plasma transaminase activity and neutrophil infiltration in the liver of carbon tetrachloride-treated mice (13). It has also been reported that ligand-activated PXR exerts anti-inflammatory effects by antagonizing nuclear factor- $\kappa \mathrm{B}(\mathrm{NF}-\kappa \mathrm{B})(14)$. Activation of the NF- $\kappa \mathrm{B}$ pathway promotes the development of NASH by enhancing the release of numerous proinflammatory cytokines, such as tumour necrosis factor- $\alpha$ (TNF- $\alpha$ ), IL-1 $\beta$ and IL-6, which further aggravate inflammatory damage in the liver (15-18). Therefore, the role of PXR in NASH is worth investigating.

The present study aimed to elucidate the therapeutic role of resveratrol in NASH, and to further investigate whether mmu-miR-599, PXR and the related inflammatory genes were involved in this effect. In addition, the present study assessed whether an interaction existed between mmu-miR-599 and PXR, in order to adequately clarify the potential molecular mechanism underlying the effects of resveratrol.

\section{Materials and methods}

Animals and treatments. A total of 18 male C57BL/6J mice (age, 8 weeks; body weight, 20-25 g) were bred in a temperature-controlled animal facility $\left(22 \pm 2^{\circ} \mathrm{C}, 50-60 \%\right.$ relative humidity) under a 12-h light-dark cycle. The mice had free access to water, and were allowed to adapt to their food and environment for 1 week before the start of the experiment. The mice were randomly divided into three groups ( $\mathrm{n}=6 \mathrm{mice} / \mathrm{group}$ ): i) Control group mice were fed a diet supplemented with choline bitartrate $(2 \mathrm{~g} / \mathrm{kg}$ ) and DL-methionine $(3 \mathrm{~g} / \mathrm{kg})(\mathrm{ICN}$ Biomedicals, Inc.); ii) methionine-choline-deficient (MCD) group mice were fed an MCD diet (ICN Biomedicals, Inc.); and iii) $\mathrm{MCD}+$ resveratrol group (RES group) mice were fed an MCD diet supplemented with resveratrol $(0.4 \mathrm{~g} / \mathrm{kg}$ daily; Shanghai Macklin Biochemical Co., Ltd.). The duration of the experiment was 4 weeks. During the experiment, the body weight and rate of diet consumption of the mice were recorded. Animals were euthanized via an intraperitoneal injection of pentobarbital sodium $(200 \mathrm{mg} / \mathrm{kg})$ after overnight fasting at the end of the experiment. Blood samples (0.3-0.6 ml/mouse) were collected from the femoral artery for biochemical analysis and enzyme-linked immunosorbent assay. Livers were weighed and fixed in $10 \%$ formalin for $24 \mathrm{~h}$ at room temperature for histological analysis or snap-frozen in liquid nitrogen followed by storage at $-80^{\circ} \mathrm{C}$ in a freezer until required. All protocols and procedures were performed following the guidelines of the Hebei Committee for Care and Use of Laboratory Animals and were approved by the Animal Experimentation Ethics Committee of Hebei Medical University (Shijiazhuang, China).

Biochemical analyses. Serum alanine aminotransferase (ALT) and aspartate aminotransferase (AST) levels were measured by the enzymatic kinetic method (cat. nos. C009-3 -1 and C010-3-1; Nanjing Jiancheng Bioengineering Institute) using an automatic biochemical analyser (UA2700; Olympus Corporation) according to the manufacturer's protocol.
Liver lipoperoxide levels were estimated by measuring malondialdehyde (MDA) levels using the OxiSelect ${ }^{\mathrm{TM}}$ thiobarbituric acid-reactive substances (TBARS) Assay kit (MDA Quantitation) (cat. no. DTBA-100; BioAssay Systems) according to the manufacturer's protocol.

Enzyme-linked immunosorbent assay. Serum was collected from whole blood samples by centrifugation $(1,250 \mathrm{x} \mathrm{g}$, $10 \mathrm{~min}$, room temperature). The serum levels of IL-1 $\beta$ (cat. no. E-EL-M0037c; Elabscience Biotechnology, Inc.), TNF- $\alpha$ (cat. no. E03T0008; BlueGene Biotechnology Co., Ltd.) and IL-6 (cat. no. BMS603HS; Thermo Fisher Scientific, Inc.) were detected using mouse enzyme-linked immunosorbent assay (ELISA) kits according to the manufacturer's protocol.

Histological analysis. Oil Red O-stained (at room temperature for $15 \mathrm{~min}$ ) frozen liver sections $(7 \mu \mathrm{m})$, and haematoxylin and eosin-stained (at room temperature, haematoxylin for $5 \mathrm{~min}$ and eosin for $1 \mathrm{~min})$ paraffin-embedded liver sections $(5 \mu \mathrm{m})$ were evaluated under a light microscope for hepatic steatosis $(0,0 \% ; 1,1-33 \% ; 2,33-66 \% ; 3,>66 \%$ hepatocytes affected $)$ and necroinflammation ( 0 , none; 1 , mild; 2 , moderate; 3 , severe) in accordance with Brunt's criteria (19), combined with the histological scoring system for NAFLD issued by the Pathology Committee of the NASH Clinical Research Network (20).

Cell culture and resveratrol intervention. Hepa1-6 cells (Cell Resource Center, Peking Union Medical College) were maintained in high-glucose Dulbecco's modified Eagle's medium (DMEM) supplemented with $100 \mathrm{U} / \mathrm{ml}$ penicillin, $100 \mathrm{~g} / \mathrm{ml}$ streptomycin and $10 \%$ foetal bovine serum (FBS), (all from Gibco; Thermo Fisher Scientific, Inc.). The cells were incubated at $37^{\circ} \mathrm{C}$ in a humidified atmosphere containing $5 \% \mathrm{CO}_{2}$.

Palmitic acid (MilliporeSigma) was conjugated to bovine serum albumin (BSA; fatty acid-free; MilliporeSigma). Hepa1-6 cells were seeded into 6-well plates, cultured to $60-70 \%$ confluence and then treated with $500 \mu \mathrm{M}$ palmitic acid (CAS: 408-35-5) for $24 \mathrm{~h}$ to establish a NASH cell model in vitro. Hepa1-6 cells incubated in palmitic acid were treated with $20 \mu \mathrm{mol} / 1 \mathrm{resveratrol}$ or solvent control (DMSO). After $24 \mathrm{~h}$ of treatment at $37^{\circ} \mathrm{C}$, cells were harvested for subsequent detection.

Mmu-miR-599 transfection in Hepal-6 cells. Untreated Hepa1-6 cells were seeded at a density of $2 \times 10^{5} / \mathrm{ml}$ and the medium was replaced with fresh DMEM without FBS and antibiotics. A total of $50 \mathrm{nM}$ mmu-miR-599 mimic or $100 \mathrm{nM}$ mmu-miR-599 inhibitor (Thermo Fisher Scientific, Inc.) was transfected into Hepa1-6 cells using Lipofectamine ${ }^{\circledR} 2000$ (Invitrogen; Thermo Fisher Scientific, Inc.) for gain- and loss-of-mmu-miR-599 function experiments, respectively. The same concentration of corresponding negative control sequences was used in miRNA experiments. After $24 \mathrm{~h}$ of culture at $37^{\circ} \mathrm{C}$ with the transfection mix, the cell culture medium was replaced with DMEM with $10 \%$ FBS and antibiotics (100 U/ml penicillin and $100 \mathrm{~g} / \mathrm{ml}$ streptomycin). A total of $48 \mathrm{~h}$ after transfection, cells were harvested by mild trypsinization and washed in phosphate-buffered saline. All experiments were repeated in triplicate. The sequences of mmu-miR-599 mimic, mmu-miR-599 inhibitor, mimic control and inhibitor control are shown in Table I. 
Table I. Sequences of mmu-miR-599 mimic, mmu-miR-599 inhibitor and relative controls.

miR name miR sequence $\left(5^{\prime}-3^{\prime}\right)$

mmu-miR-599 mimic

mmu-miR-599 mimic control

mmu-miR-599 inhibitor

mmu-miR-599 inhibitor control

UUGUGUCAGUUUAUCAAAC CCUCUUACCUCAGUUACAA GUUUGAUAAA CUGACACAA CCUCUUACCUCAGUUACAA

miR, microRNA.

Table II. Primer sequences used for reverse transcription-quantitative PCR analysis.

\begin{tabular}{|c|c|c|}
\hline Primer name & Product length (bp) & Primer sequence $\left(5^{\prime}-3^{\prime}\right)$ \\
\hline mmu-microRNA-599 & 88 & $\begin{array}{l}\text { F: TGCTGTCCACAGTGTATTTGAT } \\
\text { R: GTCATCCAGGTATGGGTTTG }\end{array}$ \\
\hline PXR & 97 & $\begin{array}{l}\text { F: GCATCCTGAGGTTCAACACG } \\
\text { R: TGGAAGCCACCATTAGGGT }\end{array}$ \\
\hline $\mathrm{NF}-\kappa \mathrm{B}$ & 168 & $\begin{array}{l}\text { F: GCGAGAGAAGCACAGATACCA } \\
\text { R: GGTCAGCCTCATAGTAGCCAT }\end{array}$ \\
\hline $\mathrm{TNF}-\alpha$ & 300 & $\begin{array}{l}\text { F: GAACTGGCAGAAGAGGCACT } \\
\text { R: AGAAGAGGCTGAGACATAGGC }\end{array}$ \\
\hline IL-1 $\beta$ & 99 & $\begin{array}{l}\text { F: AGCCCATCCTCTGTGACTCA } \\
\text { R: TTTGTTGTTCATCTCGGAGCC }\end{array}$ \\
\hline IL-6 & 131 & $\begin{array}{l}\text { F: TACCACTCCCAACAGACCTG } \\
\text { R: TCTCATTTCCACGATTTCCCAG }\end{array}$ \\
\hline NLRP3 & 128 & $\begin{array}{l}\text { F: GAAGAAGAGTGGATGGGTTTG } \\
\text { R: GCGTTCCTGTCCTTGATAGAGT }\end{array}$ \\
\hline STAT3 & 142 & $\begin{array}{l}\text { F: TGGCACCTTGGATTGAGAG } \\
\text { R: TGCTGATAGAGGACATTGGACT }\end{array}$ \\
\hline$\beta$-actin & 144 & $\begin{array}{l}\text { F: GACAGGATGCAGAAGGAGATTACTG } \\
\text { R: GCTGATCCACATCTGCTGGAA }\end{array}$ \\
\hline
\end{tabular}

PXR, pregnane X receptor; NF- $\kappa B$, nuclear factor- $\kappa B$; TNF- $\alpha$, tumour necrosis factor- $\alpha$; IL, interleukin; NLRP3, NOD-like receptor family pyrin domain-containing protein 3; STAT 3, signal transducer and activator of transcription 3; F, forward; R, reverse.

Overexpression of PXR in Hepal-6 cells. Full-length coding sequences of PXR were PCR-amplified using Thermo Scientific Phusion Flash High-Fidelity PCR Master Mix (Thermo Fisher Scientific, Inc.) and subcloned into the pcDNA3.1 plasmid (Invitrogen; Thermo Fisher Scientific, Inc.). The recombinant plasmid $(0.5 \mu \mathrm{g})$ was transfected into $70 \%$ confluent Hepa1-6 cells on a 6-well plate using Lipofectamine 2000 for PXR overexpression; the empty pcDNA3.1 plasmid was used as negative control. A total of $12 \mathrm{~h}$ before transfection, the cell culture medium was replaced with antibiotic-free medium. The cells were transfected at $37^{\circ} \mathrm{C}$ for $6 \mathrm{~h}$, then culture medium was replaced with complete medium. After $24 \mathrm{~h}$, cells were collected and subjected to subsequent experiments. The PXR expression levels were confirmed by reverse transcription-quantitative polymerase chain reaction (RT-qPCR) analysis and western blotting.

RT-qPCR analysis. RNA was isolated from liver tissues and cells using a Total RNA Extraction kit (Promega Corporation) according to the manufacturer's protocol. The isolated RNA was then reverse transcribed into cDNA at $25^{\circ} \mathrm{C}$ for $10 \mathrm{~min}$ and then at $42^{\circ} \mathrm{C}$ for $60 \mathrm{~min}$ with dNTPs $(10 \mathrm{mM})$ and $5 \mathrm{X} \mathrm{M}-\mathrm{MLV}$ buffer using the M-MLV RT kit (Promega Corporation) with either miRNA-specific stem-loop primers (Promega Corporation) or oligo dT primers (Sangon Biotech Co., Ltd.). Differential RT-qPCR was performed on an ABI 7500 Real-Time PCR system (Applied Biosystems; Thermo Fisher Scientific, Inc.) using SYBR-Green master mix (Promega Corporation). The thermocycling conditions for $\mathrm{qPCR}$ were as follows: $95^{\circ} \mathrm{C}$ for $5 \mathrm{~min}$; followed by 40 cycles at $95^{\circ} \mathrm{C}$ for $30 \mathrm{sec}$ and $60^{\circ} \mathrm{C}$ for $1 \mathrm{~min}$. The relative abundance of miRNA was normalized to the small nuclear RNA U6 and the expression levels of the genes were normalized to the endogenous reference gene $\beta$-actin. The relative amounts of the miRNAs and genes were measured using the $2^{-\Delta \Delta \mathrm{Cq}}$ method (21). RT-qPCR was conducted in triplicate and the primers used are shown in Table II. 

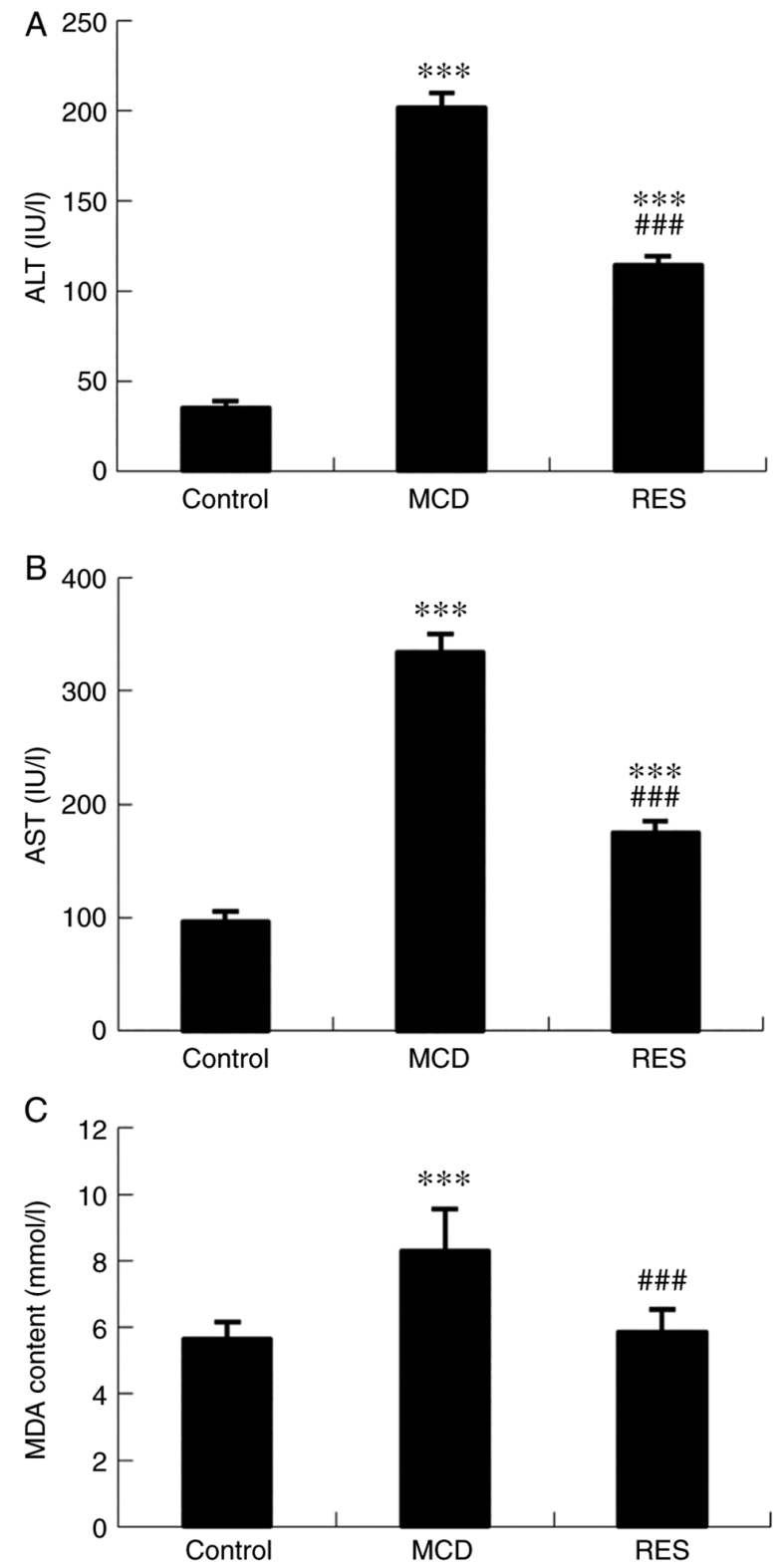

Figure 1. Effects of resveratrol on serum aminotransferase and liver lipoperoxide levels. (A) Serum ALT levels, (B) AST levels and (C) hepatic MDA content in mice with steatohepatitis. Data are expressed as the mean $\pm \mathrm{SD}$ ( $\mathrm{n}=6$ per group). ${ }^{* * *} \mathrm{P}<0.001$ compared with control group; ${ }^{\# \# \#} \mathrm{P}<0.001$ compared with MCD group. ALT, alanine aminotransferase; AST, aspartate aminotransferase; MDA, malondialdehyde; MCD, methionine-choline-deficient; RES, MCD + resveratrol group.

Western blot analysis. Total protein was extracted from liver tissues and cells with an ExKine ${ }^{\mathrm{TM}}$ Total Protein Extraction kit (Abbkine Scientific Co., Ltd.) and the concentration was measured with a Protein Quantification kit (BCA Assay) (AmyJet Scientific, Inc.). Equal amounts of protein (50 $\mu \mathrm{g} /$ well) were separated by SDS-PAGE on $10 \%$ gels and proteins were transferred onto equilibrated polyvinylidene difluoride membranes (Amersham; Cytiva) by electroblotting. Membranes were blocked with $1 \%$ BSA at room temperature for $2 \mathrm{~h}$ and the membranes were then incubated with primary antibodies against PXR (cat. no. sc-48340), TNF- $\alpha$ (cat. no. sc-52746), IL-1 $\beta$ (cat. no. sc-12742), IL-6 (cat. no. sc-57315), NF- $\mathrm{BB}$ (cat. no. sc-8008), NOD-like receptor protein 3 (NLRP3) (cat. no. sc-134306) and signal transducer and activator of transcription 3 (STAT3) (cat. no. sc-8019) (1:500; all from Santa Cruz Biotechnology, Inc.) overnight at $4^{\circ} \mathrm{C}$. Membranes were further incubated with HRP-labeled secondary antibodies (1:10,000; cat. nos. PA174421 for goat anti-mouse secondary antibody, PA184709 for goat anti-rat secondary antibody, PA128823 for goat anti-hamster secondary antibody; Thermo Fisher Scientific, Inc.) for $1 \mathrm{~h}$ at room temperature. Proteins were detected by enhanced chemiluminescence (ECL; Amersham; Cytiva). $\beta$-actin (Wuhan Boster Biological Technology, Ltd.) served as a loading control. The intensity of each protein band of interest was semi-quantified by densitometry using ImageJ software (V1.8.0; National Institutes of Health).

Luciferase activity assay. The online database miRDB (http://www.mirdb. org/custom.html) was used for sequence verification, and PXR was predicted as a potential target gene of mmu-miR-599. Their relationship was further verified by luciferase activity assay. Sequences containing the wild-type or mutant seed region of the PXR 3'UTR were synthesized and cloned into the pGL3-Basic luciferase vector (Promega Corporation). An empty luciferase reporter vector was used as a negative control. Briefly, 70\% confluent 293T cells (Cell Resource Center, Peking Union Medical College) were cultured in 24-well plates and each well was transfected at $37^{\circ} \mathrm{C}$ with $200 \mathrm{ng}$ luciferase reporter constructs and $50 \mathrm{nM}$ mmu-miR-599 mimic or mimic control using Lipofectamine 2000 transfection reagent according to the manufacturer's protocol. Cells were transfected for $6 \mathrm{~h}$ at $37^{\circ} \mathrm{C}$, and transfection medium was replaced with DMEM containing $10 \%$ FBS. Cells were harvested and luciferase activity was assessed $24 \mathrm{~h}$ after transfection using the Dual-Luciferase Assay System (Promega Corporation). Renilla luciferase activity served as an internal control.

Statistical analysis. All experiments were conducted in triplicate and all data are expressed as the mean \pm standard deviation (SD). One-way analysis of variance or Kruskal-Wallis $\mathrm{H}$ test, with least significant difference-t test or Dunn's test for post hoc comparison, was used when three groups were compared. Two-tailed unpaired t-test or Mann-Whitney U test was used when two groups were compared. Statistical analysis was performed using SPSS 26.0 (SPSS, Inc.). $\mathrm{P}<0.05$ was considered to indicate a statistically significant difference.

\section{Results}

Effect of resveratrol on inflammatory liver injury and oxidative stress in mice with NASH. As shown in Fig. 1, mice fed an MCD diet had significantly higher serum ALT and AST levels, indicating hepatic injury. Significant reductions in serum ALT and AST levels were observed following resveratrol treatment. Hepatic MDA was analysed as a marker of oxidative stress. The increased hepatic lipid peroxidation level induced by the MCD diet was significantly reduced by resveratrol (Fig. 1C).

Effect of resveratrol on body weight and liver weight changes. Administration of the MCD diet caused body weight loss and an increase in liver-to-body weight ratio in mice. Resveratrol 
A
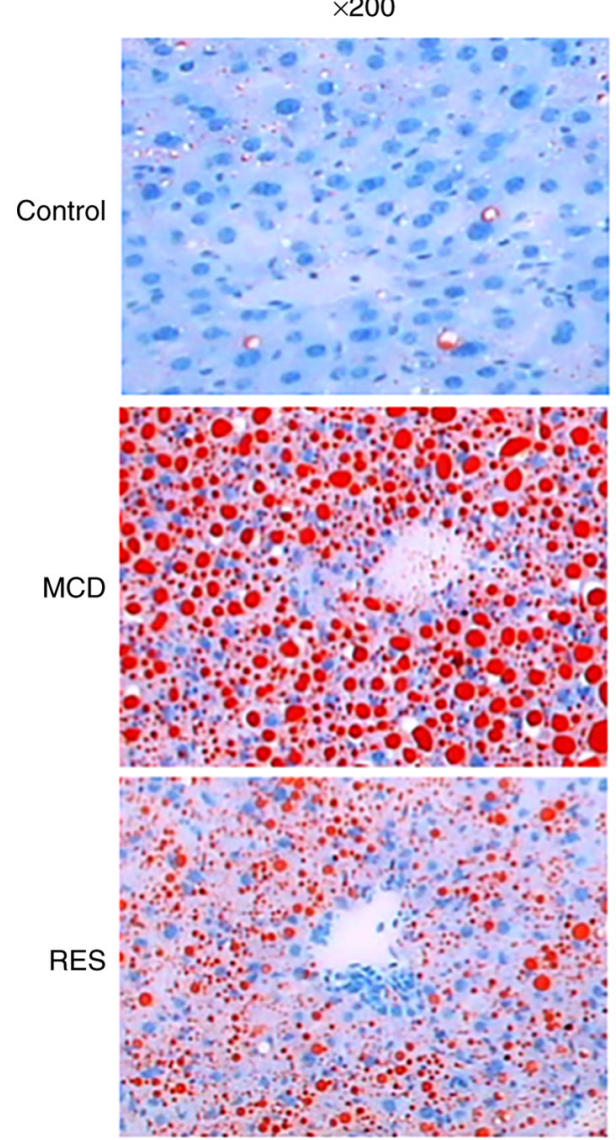

Hematoxylin and eosin stain $\times 200$
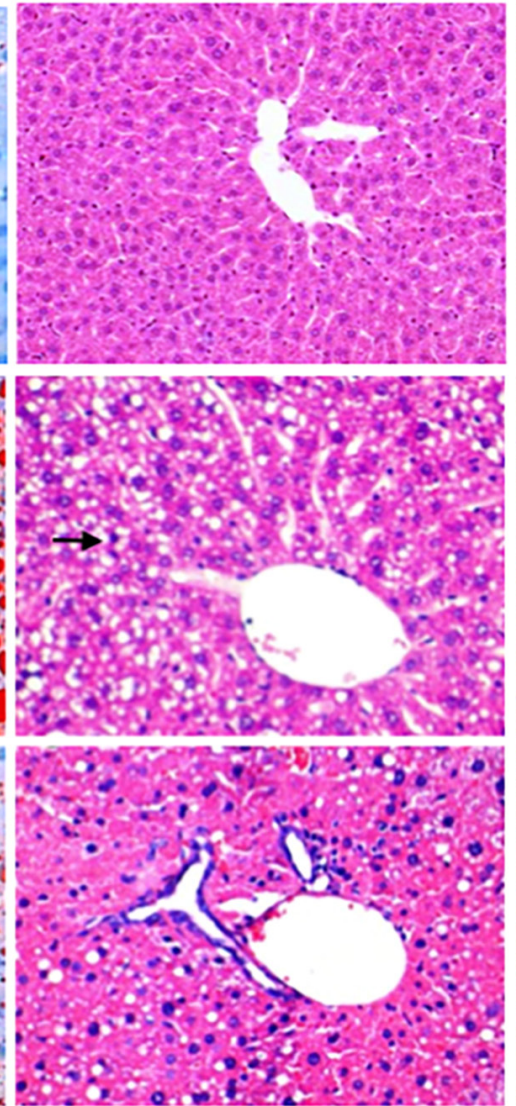

Hematoxylin and eosin stain $\times 400$
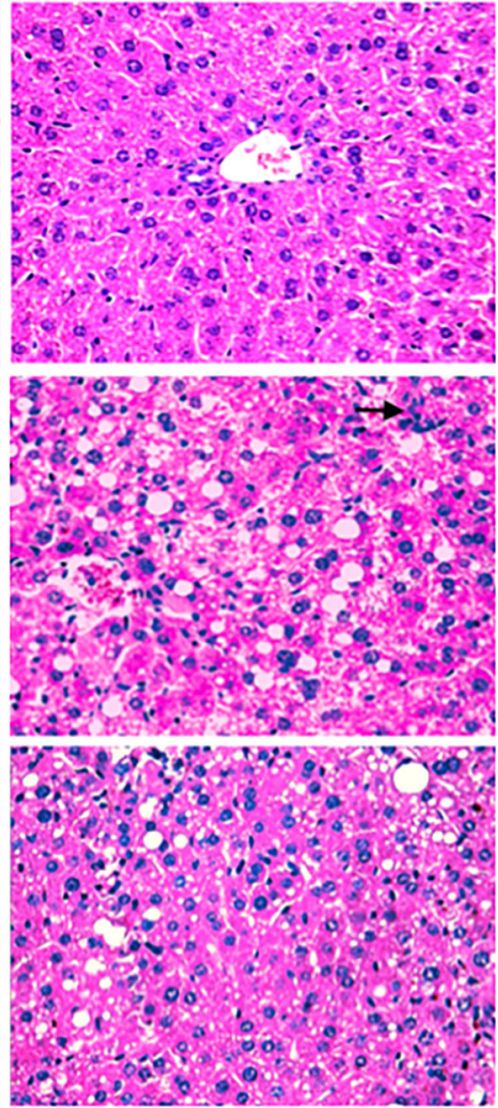

B

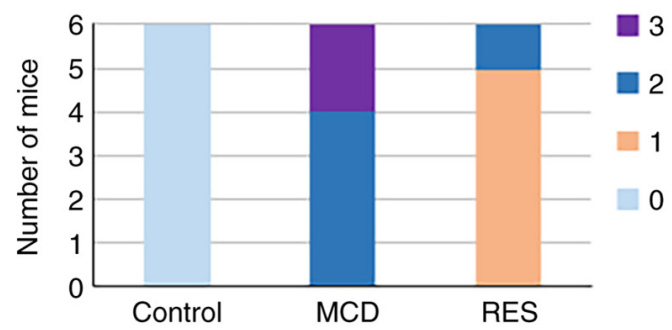

Steatosis
ㄴ 3

2

1

(1)

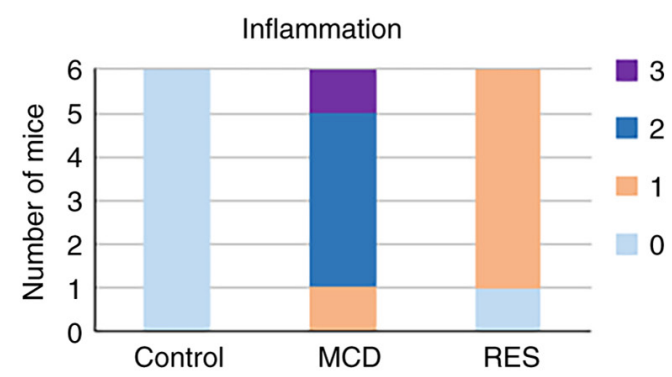

Figure 2. Histopathological changes of mice under various treatment conditions. (A) Oil-Red-O stained (magnification, x200) and hematoxylin and eosin-stained (magnifications, x200 and x400) liver sections from Control, MCD and RES groups. Arrows indicate points of focal hepatocyte necrosis and inflammatory infiltration. (B) Distribution of mice with different pathological scores. MCD, methionine-choline-deficient; RES, MCD + resveratrol group.

had no effects on body and liver-to-body weight ratio in NASH mice (Table III).

Reversal of hepatic pathological changes after resveratrol treatment in mice with NASH. The liver sections obtained from mice in the MCD group exhibited disordered lobule structure, severe macrosteatosis, spot or focal hepatocyte necrosis, and mixed inflammatory cell infiltration (Fig. 2A). Accordingly, mice fed a MCD diet exhibited higher histological scores for liver steatosis and inflammation compared with control mice (Fig. 2B). Resveratrol administration could markedly ameliorate hepatic steatosis and necrotic inflammation.

Ectopic expression of mmu-miR-599 and PXR in mice. As revealed in Fig. 3, the MCD diet significantly upregulated the expression levels of mmu-miR-599, and downregulated the
Table III. Body weight and liver-to-body weight ratio of mice.

\begin{tabular}{lcc}
\hline Group & Body weight (g) & Liver-to-body weight ratio (\%) \\
\hline Control & $24.00 \pm 1.78$ & $4.00 \pm 0.59$ \\
MCD & $10.95 \pm 0.34^{\mathrm{a}}$ & $4.49 \pm 0.21^{\mathrm{b}}$ \\
RES & $11.60 \pm 0.25^{\mathrm{a}}$ & $4.70 \pm 0.21^{\mathrm{c}}$ \\
\hline
\end{tabular}

Data are presented as the mean $\pm \mathrm{SD} .{ }^{\mathrm{a}} \mathrm{P}<0.001,{ }^{\mathrm{b}} \mathrm{P}<0.05$ and ${ }^{\mathrm{c}} \mathrm{P}<0.01$ compared with Control group. MCD, methionine-choline-deficient; RES, MCD + resveratrol group.

mRNA and protein expression levels of PXR. Mice treated with resveratrol showed reduced mmu-miR-599 expression and increased PXR expression. 

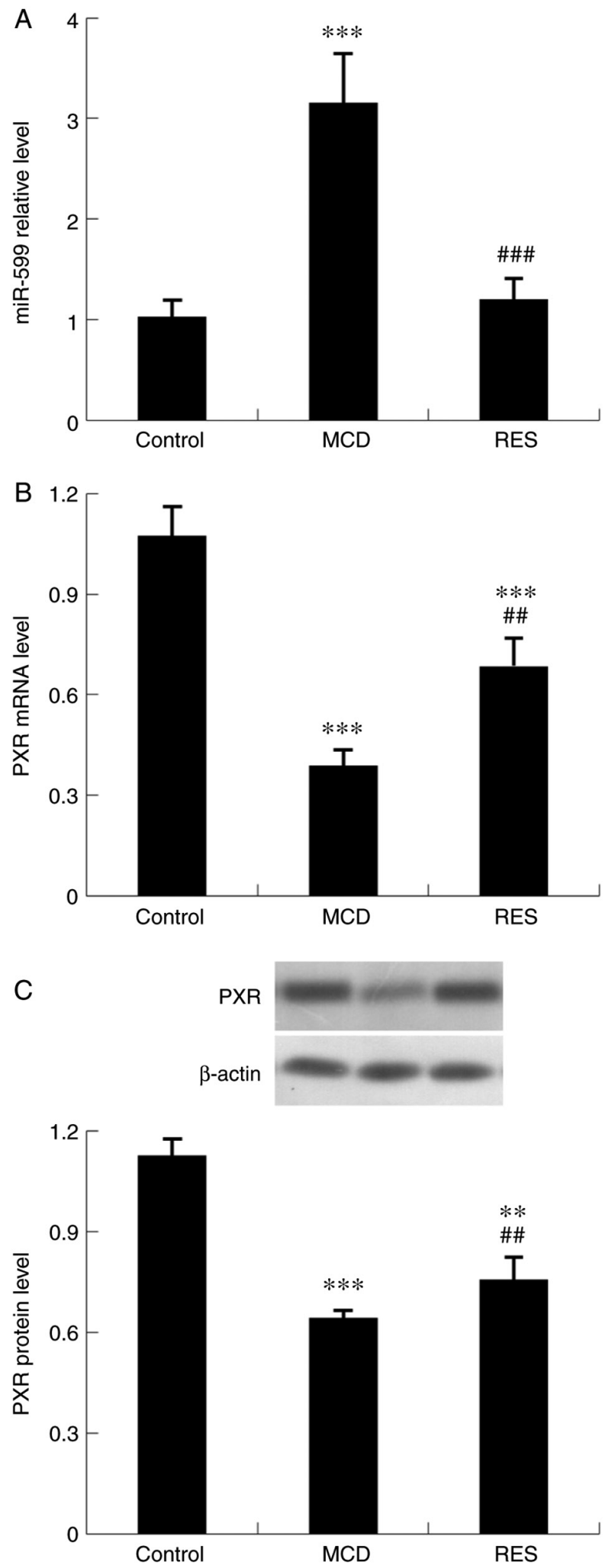

Figure 3. Effect of resveratrol on hepatic expression of mmu-miR-599 and PXR in mice with steatohepatitis. Expression levels of (A) mmu-miR-599, (B) PXR mRNA and (C) PXR protein. Data are expressed as the mean $\pm \mathrm{SD}$ (n=6 per group). ${ }^{* *} \mathrm{P}<0.01$ and ${ }^{* * * *} \mathrm{P}<0.001$ compared with control group ${ }^{\# \#} \mathrm{P}<0.01$ and ${ }^{\# \# \#} \mathrm{P}<0.001$ compared with MCD group. miR, microRNA; $\mathrm{PXR}$, pregnane $\mathrm{X}$ receptor; $\mathrm{MCD}$, methionine-choline-deficient RES, MCD + resveratrol group.

Effect of resveratrol on inflammation-related genes in mice with NASH. To identify the mechanism underlying the
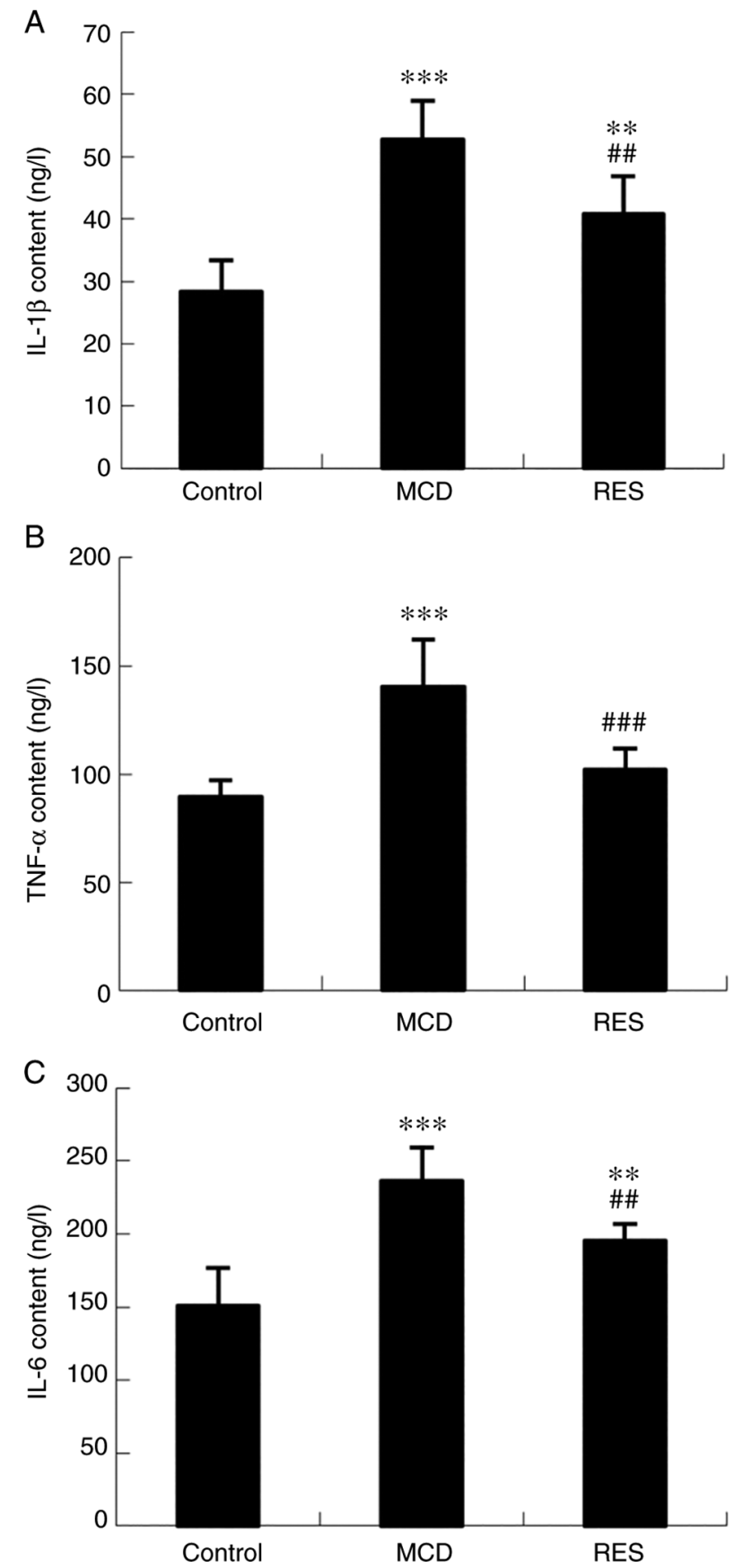

Figure 4. Effect of resveratrol on serum levels of IL-1 $\beta$, TNF- $\alpha$ and IL-6 in mice with steatohepatitis. Serum levels of (A) IL-1 $\beta$, (B) TNF- $\alpha$ and (C) IL-6. Data are expressed as the mean $\pm \mathrm{SD}$ ( $\mathrm{n}=6$ per group). ${ }^{* *} \mathrm{P}<0.01$ and ${ }^{* * * *} \mathrm{P}<0.001$ compared with control group; ${ }^{\# \#} \mathrm{P}<0.01$ and ${ }^{\# \# \#} \mathrm{P}<0.001$ compared with MCD group. MCD, methionine-choline-deficient; RES, MCD + resveratrol group; IL, interleukin; TNF- $\alpha$, tumour necrosis factor- $\alpha$.

amelioration of liver injury induced by resveratrol administration, the serum and hepatic expression levels of proinflammatory factors were assessed. Serum levels of IL-1 $\beta, \mathrm{TNF}-\alpha$ and IL-6 (Fig. 4), and hepatic expression levels of NF-кB, IL-1 $\beta$, TNF- $\alpha$, IL-6, NLRP3 and STAT3 (Fig. 5) were increased in NASH mice. Treatment with resveratrol significantly reduced the hepatic mRNA expression levels of these inflammatory factors. Concomitant with the reduction in mRNA expression, the serum protein levels of IL-1 $\beta$, TNF- $\alpha$ and IL-6, and the hepatic protein expression levels of NF- $\kappa B$, IL-1 $\beta$, 


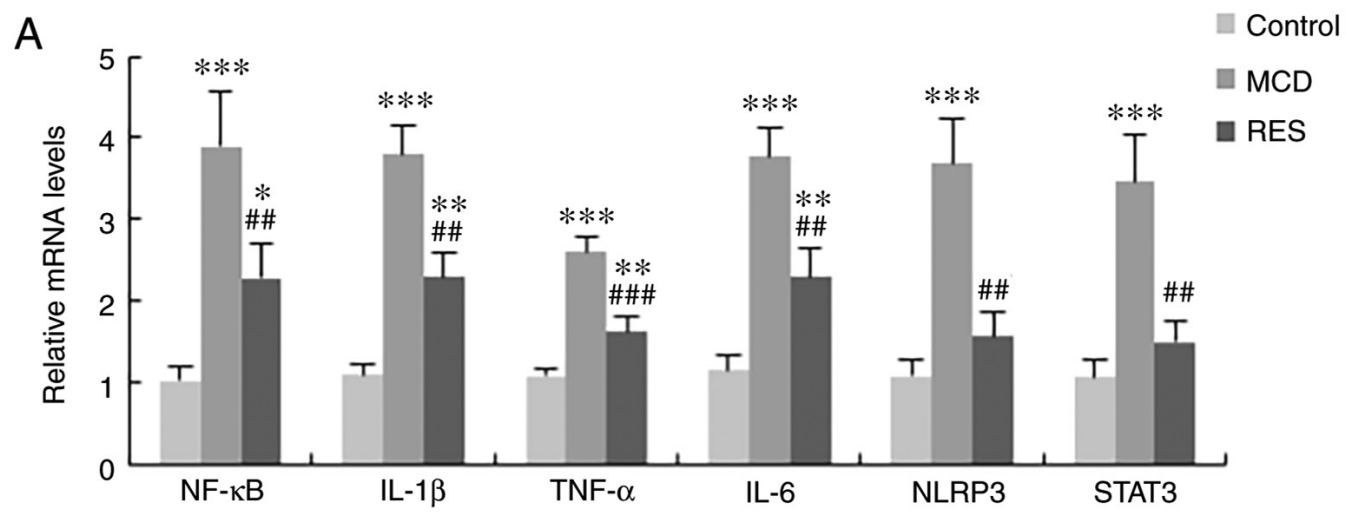

B
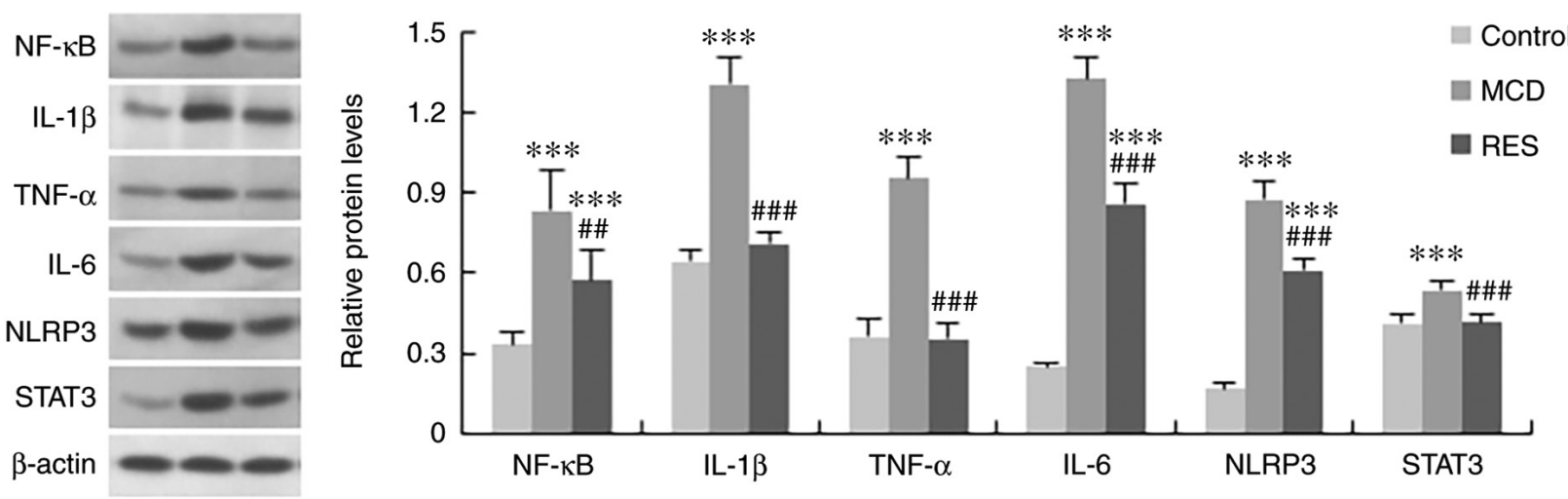

Figure 5. Effect of resveratrol on the expression of inflammation-related genes in the liver of mice with steatohepatitis. (A) mRNA and (B) protein expression levels of NF- $\kappa$ B, IL-1 $\beta$, TNF- $\alpha$, IL-6, NLRP3 and STAT3 in the three treatment groups. Data are expressed as the mean \pm SD ( $=6$ per group). ${ }^{*}<0.05$, ${ }^{* *} \mathrm{P}<0.01$ and ${ }^{* * *} \mathrm{P}<0.001$ compared with control group; ${ }^{\# \#} \mathrm{P}<0.01$ and ${ }^{\# \#} \mathrm{P}<0.001$ compared with MCD group. MCD, methionine-choline-deficient; RES, $\mathrm{MCD}+$ resveratrol group; NF- $\kappa \mathrm{B}$, nuclear factor- $\kappa \mathrm{B}$; IL, interleukin; TNF- $\alpha$, tumour necrosis factor- $\alpha$; NLRP3, NOD-like receptor protein 3; STAT3, signal transducer and activator of transcription 3 .

TNF- $\alpha$, IL-6, NLRP3 and STAT3 were also downregulated by resveratrol.

Effect of resveratrol on the expression of mmu-miR-599 and PXR in Hepal-6 cells. The regulatory effects of resveratrol on the expression of mmu-miR-599 and PXR in Hepa1-6 cells were further verified. As demonstrated in Fig. 6, resveratrol downregulated the expression levels of mmu-miR-599, but upregulated the mRNA and protein expression levels of PXR compared with in the model group.

Effect of mmu-miR-599 on the expression of PXR in Hepal-6 cells. To determine the association between mmu-miR-599 and PXR, mmu-miR-599 was regulated in Hepa1-6 cells via transfection with mmu-miR-599 mimic or inhibitor (Fig. 7), and the expression levels of PXR were detected. As shown in Fig. 8C and D, PXR mRNA and protein expression levels were increased in Hepa1-6 cells transfected with mmu-miR-599 inhibitor, whereas their expression levels were decreased in cells transfected with mmu-miR-599 mimic.

Effect of PXR on the expression of inflammatory factors in Hepal-6 cells. The role of PXR in the development of liver inflammation was further evaluated by assessing the expression levels of inflammatory factors in Hepa1- 6 cells overexpressing PXR. As revealed in Figs. 9 and 10, overexpression of PXR significantly suppressed the mRNA and protein expression levels of inflammatory factors, including NF- $\mathrm{NB}, \mathrm{IL}-1 \beta$, TNF- $\alpha$, IL-6, NLRP3 and STAT3.

Binding site of mmu-miR-599 in the PXR mRNA sequence. The binding site of mmu-miR-599 in the PXR mRNA sequence was verified by the site mutation in luciferase activity assay, which confirmed that miR-599 suppressed PXR expression at mRNA level. The predicted binding site was shown in Fig. 8A, which showed that six nucleotides in the seed region of mmu-miR-599 were complementary to bases in PXR. To determine whether mmu-miR-599 directly binds to the predicated sites in the PXR 3'UTR, a luciferase reporter assay was performed. Transfection with the mmu-miR-599 mimic significantly reduced PXR 3'UTR-dependent luciferase activity but did not affect mutant reporter luciferase activity. In addition, the mimic control had no effect on wild-type or mutant reporter luciferase activity (Fig. 8B).

\section{Discussion}

Feeding mice a MCD diet is a representative and very reproducible nutritional model of NASH, which can lead to body weight loss due to methionine and choline deficiency in the diet $(22,23)$. C57BL/6J mice fed an MCD diet for 4 weeks rapidly and consistently developed steatohepatitis. Resveratrol administration attenuated liver injury, as evidenced by the diminished histological injury and decreased aminotransferase 
A

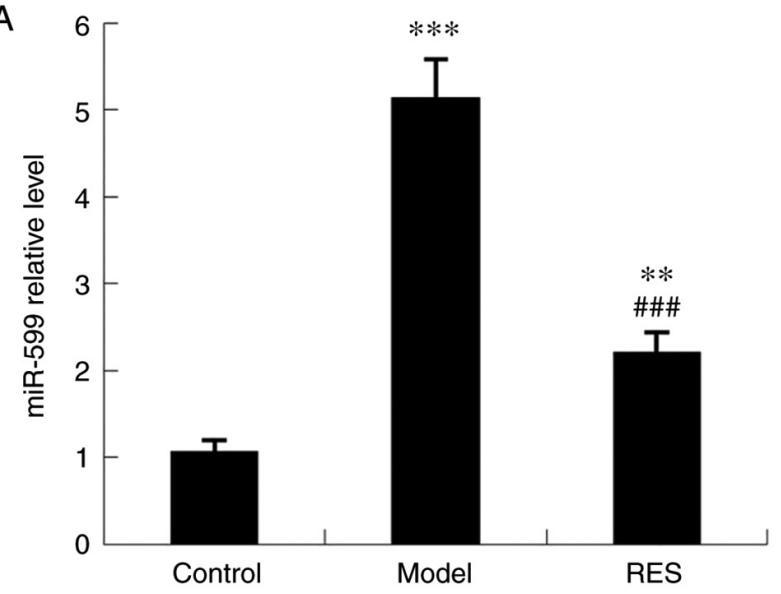

B

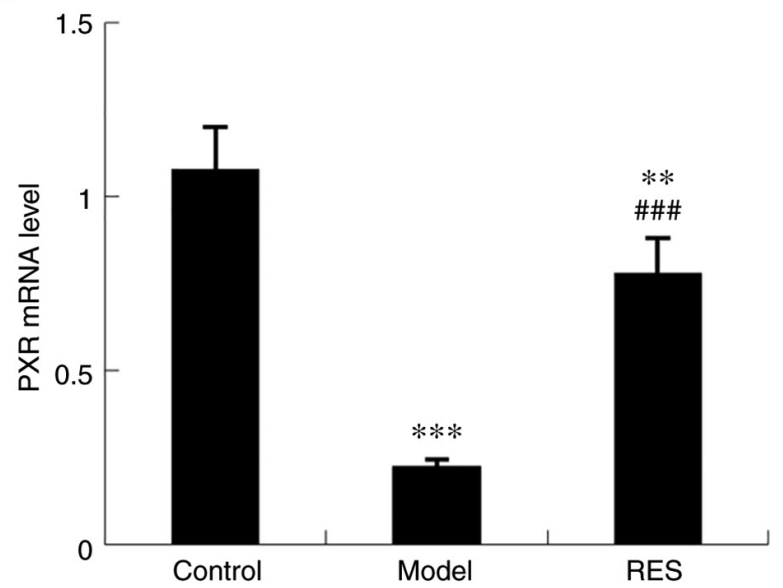

C

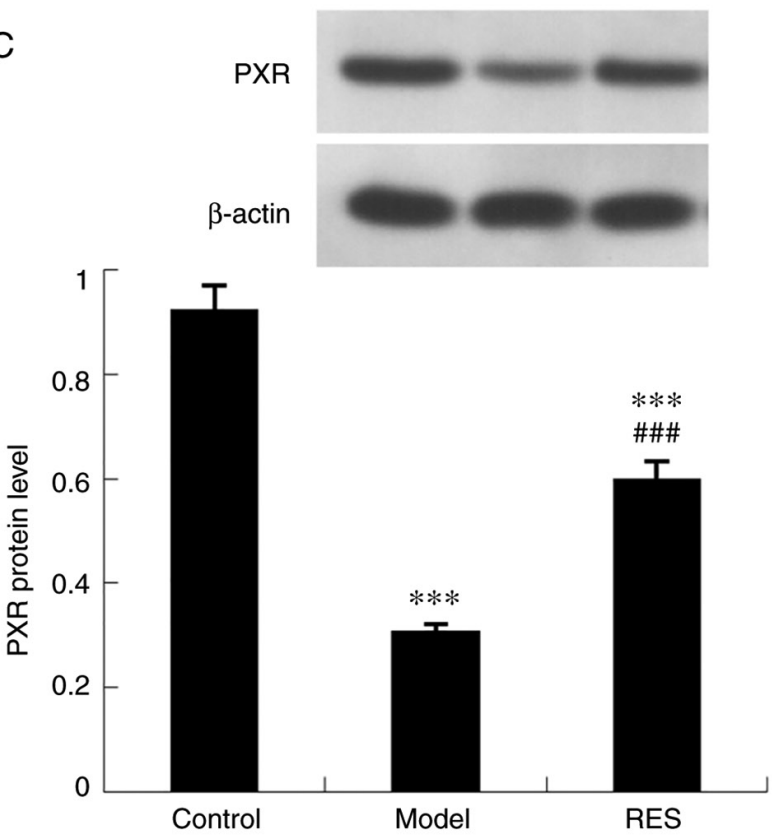

Figure 6. Effect of resveratrol on the expression levels of mmu-miR-599 and PXR in Hepa1-6 cells. Expression levels of (A) mmu-miR-599, (B) PXR mRNA and $(C)$ PXR protein. Data are expressed as the mean \pm SD $(n=6$ per group). ${ }^{* *} \mathrm{P}<0.01$ and ${ }^{* * *} \mathrm{P}<0.001$ compared with control group; ${ }^{\# \# \#} \mathrm{P}<0.001$ compared with model group. PXR, pregnane $\mathrm{X}$ receptor; miR, microRNA; RES, palmitic acid + resveratrol group.

levels. Resveratrol has been reported to reduce hepatic lipogenesis by activating the adenosine monophosphate-activated

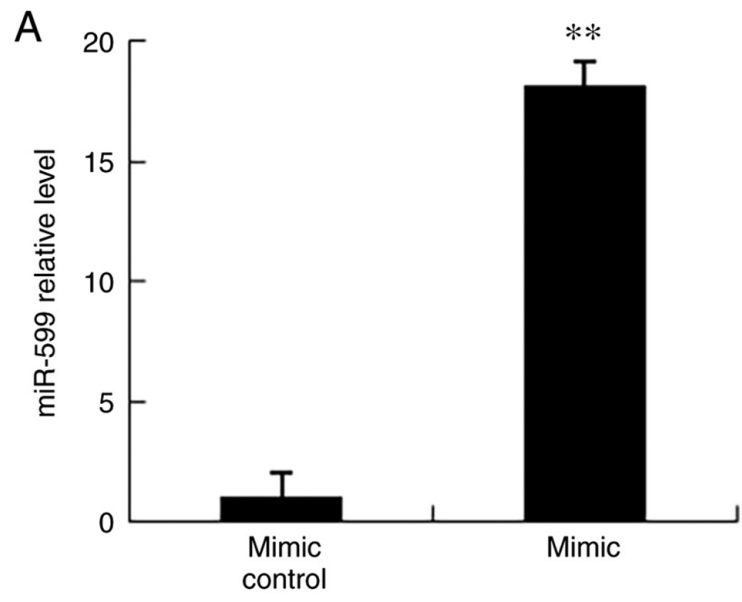

B

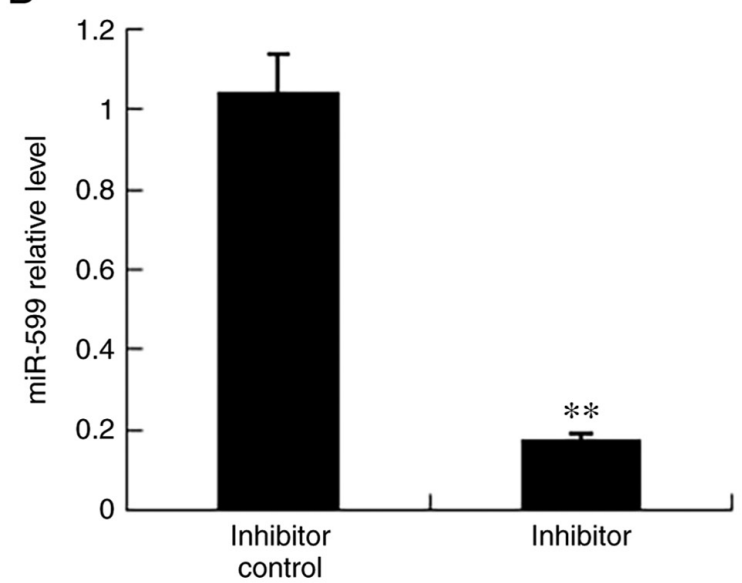

Figure 7. Mmu-miR-599 regulation in Hepa1-6 cells. (A) Mmu-miR-599 expression regulated by mmu-miR-599 mimic. ${ }^{* *} \mathrm{P}<0.01$ compared with mimic control group. (B) Mmu-miR-599 expression regulated by mmu-miR-599 inhibitor. ${ }^{* *} \mathrm{P}<0.01$ compared with inhibitor control group. Data are expressed as the mean $\pm \mathrm{SD}$ ( $\mathrm{n}=6$ per group). $\mathrm{miR}$, microRNA.

protein kinase (AMPK)/silent information regulation-2 homologue 1 (SIRT1) pathway and consequently inhibiting adipogenesis-related genes, including sterol regulatory element-binding protein-1c, acetyl-CoA carboxylase and fatty acid synthase (24-26). In addition to the anti-steatotic effect through AMPK/SIRT1 activation, resveratrol has antioxidant and anti-inflammatory effects, and these effects may act in unison, combating different pathological injuries in the pathogenesis of NASH development $(5,6)$.

Pathological accumulation of lipids in the liver can induce lipid peroxidation and excessive reactive oxygen species generation, which can lead to oxidative stress (27). It has been demonstrated that liver lipoperoxide levels are elevated in mice with steatohepatitis. Oxidative stress can mediate inflammatory recruitment directly or indirectly by activating inflammatory cytokines, which can result in cellular injury and inflammatory recruitment (27). In the present study, resveratrol attenuated oxidative stress, as evidenced by decreased MDA levels, and improved hepatic inflammation in MCD diet-induced steatohepatitis. The anti-inflammatory effect may be the result of the decreased expression levels of the key inflammatory markers NF- $\mathrm{KB}$, IL-1 $\beta$, TNF- $\alpha$ and IL-6. 
A

PXR (WT)

mmu-miR-599

PXR (MUT)

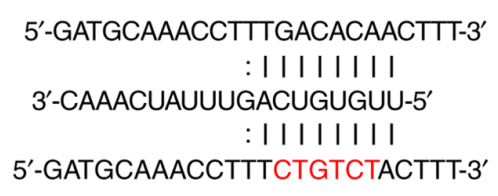

B

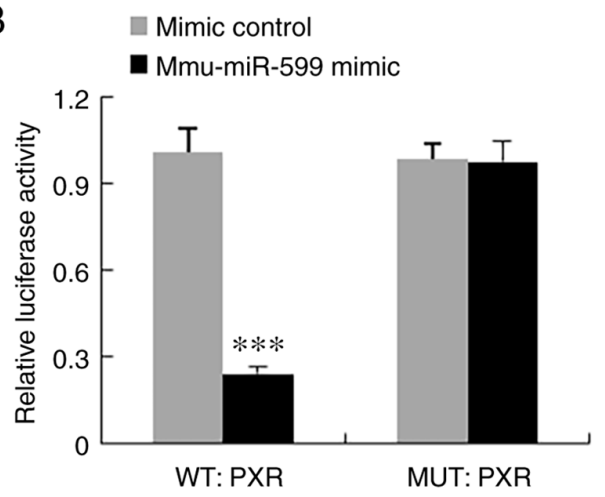

C
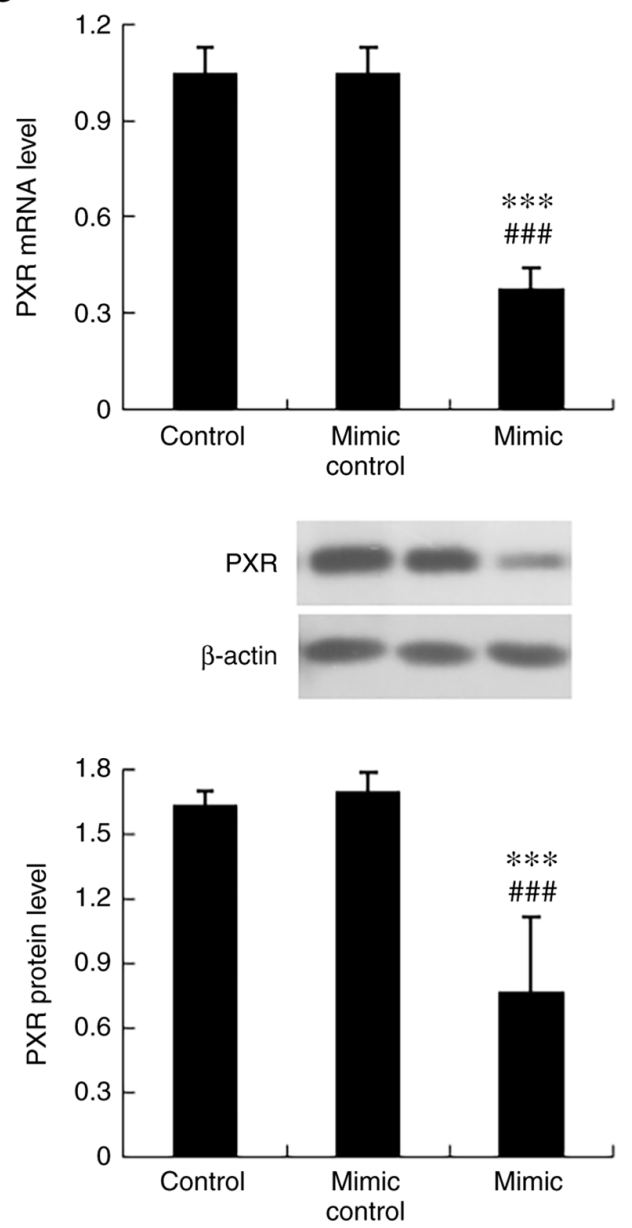

D
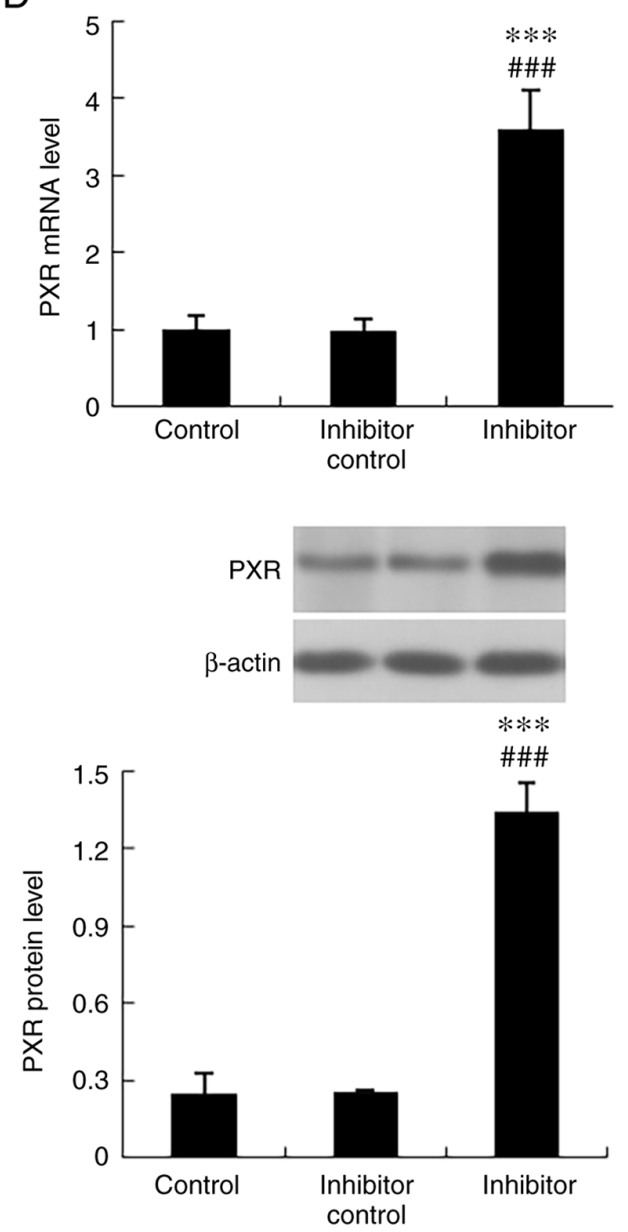

Figure 8. Experimental validation of PXR as a target gene of mmu-miR-599. (A) Mmu-miR-599 potential binding sites on the 3'untranslated region of PXR. (B) Relative luciferase activity. ${ }^{* * *} \mathrm{P}<0.001$ compared with mimic control group. (C) Expression levels of PXR regulated by mmu-miR-599 mimic. ${ }^{* * *} \mathrm{P}<0.001$ compared with control group; ${ }^{\# \#} \mathrm{P}<0.001$ compared with mimic control group. (D) Expression levels of $\mathrm{PXR}$ regulated by mmu-miR-599 inhibitor. ${ }^{* * *} \mathrm{P}<0.001$ compared with control group; ${ }^{\# \#} \mathrm{P}<0.001$ compared with inhibitor control group. Data are expressed as the mean $\pm \mathrm{SD}$ ( $\mathrm{n}=6 \mathrm{per}$ group). PXR, pregnane $\mathrm{X}$ receptor; miR, microRNA; WT, wild type; MUT, mutant.

Previously, miRNAs have been shown to play important roles in NASH (9). In the present study, mmu-miR-599 expression was increased in the livers of NASH model mice. miR-599 has been reported to promote the inflammatory response. Proinflammatory marker production reflected consistent inflammation, as miR-599 promoted the expression of TNF- $\alpha$ and IL-6 (11). In addition, the present study revealed that resveratrol downregulated the expression levels of mmu-miR-599 in NASH model mice and Hepa1-6 cells. Therefore, it was hypothesized that the anti-inflammatory effects of resveratrol may be mediated by mmu-miR-599; however, the detailed mechanisms need to be explored.

The nucleotides of the seed sequence of miRNAs match the target mRNA, and miRNAs silence specific genes by inhibiting the translation of the target mRNA or affecting the stability of the mRNA (7). In the present study, PXR expression was decreased in the livers of mice with NASH. Resveratrol increased PXR expression in mice and Hepa1-6 cells; the effects of resveratrol on PXR were in contrast to those on mmu-miR-599. In Hepa1-6 cells, the mmu-miR-599 mimic 
B

A

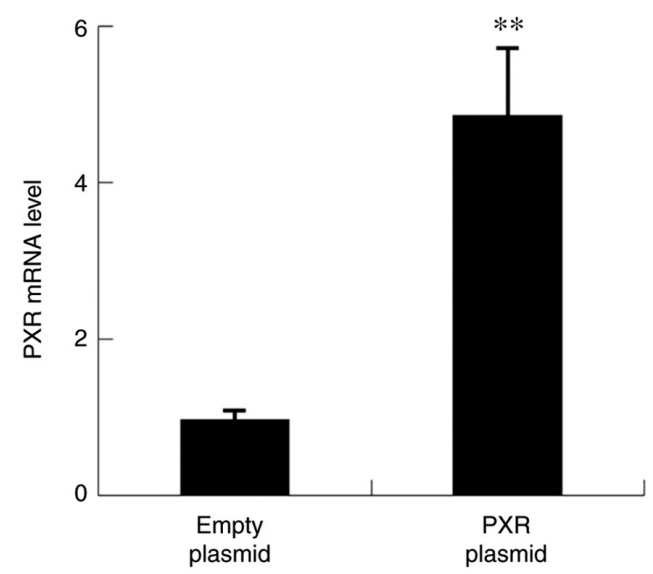

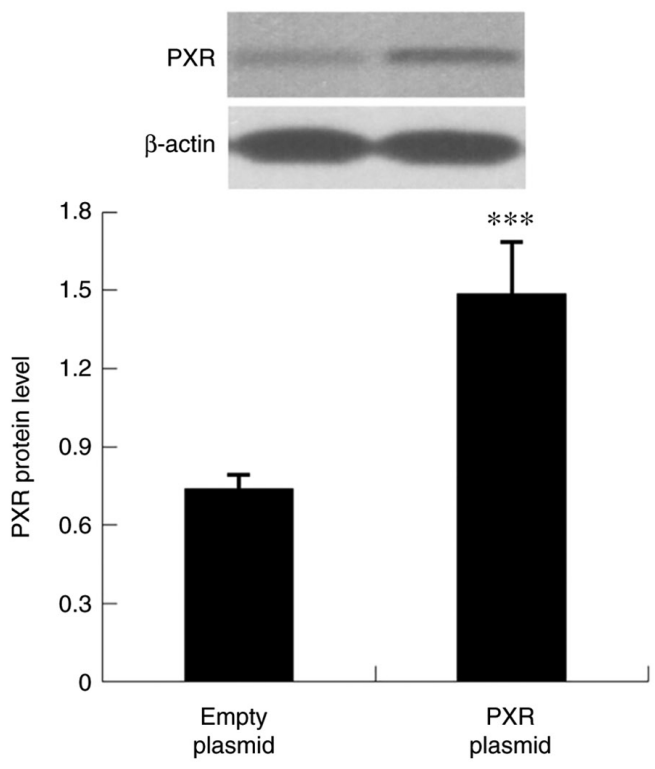

Figure 9. PXR overexpression in Hepa1-6 cells. (A) mRNA and (B) protein expression levels of PXR. Data are expressed as the mean \pm SD ( $\mathrm{n}=6$ per group). ${ }^{* *} \mathrm{P}<0.01,{ }^{* * * *} \mathrm{P}<0.001$ compared with empty plasmid group. $\mathrm{PXR}$, pregnane $\mathrm{X}$ receptor.

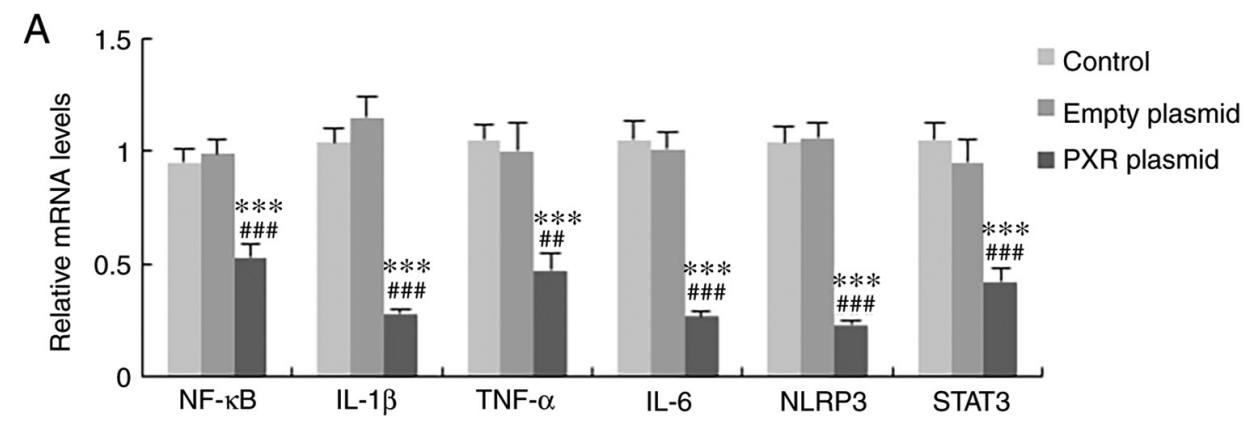

B
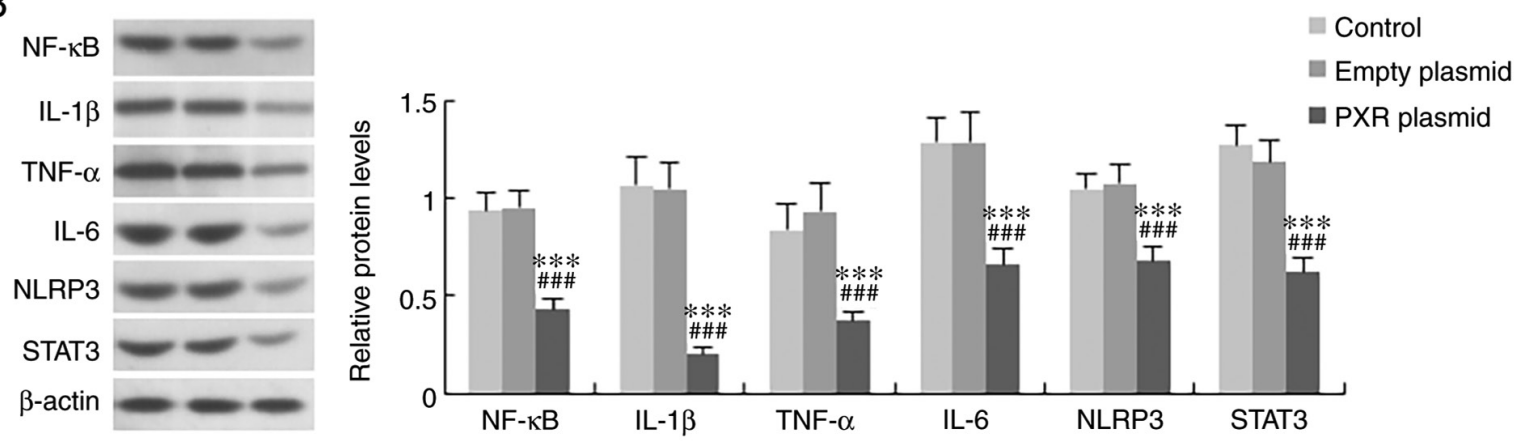

Figure 10. Effect of PXR on the expression levels of inflammatory factors in Hepa1-6 cells. (A) mRNA and (B) protein expression levels of NF- $\kappa B$, IL-1 1 , TNF- $\alpha$, IL-6, NLRP3 and STAT3 in the three treatment groups. Data are expressed as the mean $\pm \mathrm{SD}$ ( $\mathrm{n}=6$ per group). ${ }^{* * *} \mathrm{P}<0.001$ compared with control group;

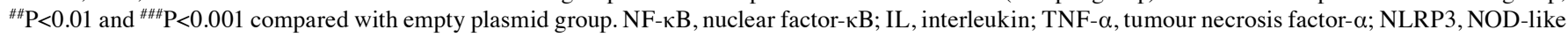
receptor protein 3; STAT3, signal transducer and activator of transcription 3; PXR, pregnane X receptor.

significantly suppressed the mRNA and protein expression levels of PXR, whereas the mmu-miR-599 inhibitor induced the opposite effect. The mmu-miR-599 binding site was further detected in the mRNA sequence of PXR, indicating that the expression of PXR was inhibited by mmu-miR-599 at the transcriptional level. Therefore, the effect of resveratrol on NASH may be mediated by the mmu-miR-599/PXR pathway.

To explore the downstream genes regulated by mmu-miR-599/PXR, the expression of PXR in Hepa1-6 cells was enhanced and it was revealed that the overexpression of
PXR downregulated inflammatory factors. In line with the present results, previous studies revealed that PXR can exert anti-inflammatory effects by suppressing NF- $\mathrm{B}$ and inhibiting its function of regulating the expression of target genes, such as TNF- $\alpha$ and IL-1 $\beta(28,29)$. Reporter gene assays with NF- $\kappa$ B-binding motifs have suggested that NF- $\kappa \mathrm{B}$-dependent gene transcription can be prevented by human PXR binding with its ligand in a dose-dependent manner (30). Additionally, it has been reported that PXR may reduce Toll-like receptor 4 (TLR4) expression by decreasing its mRNA stability 
in necrotizing enterocolitis (31). Notably, the TLR4-dependent signalling pathway of IKK- $\beta / \mathrm{NF}-\kappa \mathrm{B}$ is involved in the development of NASH (15). TLR4 is a pattern recognition receptor that triggers different inflammatory responses. As an inflammatory inducing factor, $\mathrm{NF}-\kappa \mathrm{B}$ regulates proinflammatory cytokines, including iNOS, COX-2 and TNF- $\alpha$, ultimately leading to inflammatory injury (32). Overall, PXR may downregulate $\mathrm{NF}-\kappa \mathrm{B}$ directly, or through inhibiting TLR4 signalling.

The JNK1/activator protein 1 (AP-1) pathway is another downstream pathway of TLR4. Inflammation-related genes are also regulated by the transcription factor AP-1 (33). NF- $\kappa \mathrm{B}$ and AP-1 work with each other to respond to inflammatory signals. Okamura et al (13) reported that TNF- $\alpha$-induced chemokine $\mathrm{Cxcl} 2$ expression was suppressed by PXR. In addition, $\mathrm{NF}-\kappa \mathrm{B}$ inhibitor or mutation of an NF- $\mathrm{NB}$-binding motif partly reduced PXR-dependent suppression of $\mathrm{Cxcl} 2$, whereas the mutation of both the NF- $\kappa$ B and AP-1 sites abolished this effect. Consistently, AP-1-dependent gene transcription was suppressed by PXR with a construct containing AP-1 binding motifs. Therefore, these findings indicated that PXR may exert anti-inflammatory effects by suppressing both NF- $\mathrm{BB}$ - and AP-1-dependent inflammatory cytokine and chemokine expression.

The expression of NLRP3 was increased in NASH mice in the present study. In recent years, the NLRP3 inflammasome has been identified as an important trigger of liver inflammation in NASH (34). IL-1 $\beta$ signalling acts as an important contributor to liver injury resulting from NLRP3 activation (35). Notably, an interaction between NLRP3 and the TLR4 pathway has been identified. The induction of NLRP3 and pro-IL-1 $\beta$ depends on $\mathrm{NF}-\kappa \mathrm{B}$; in turn, IL-1 $\beta$, which binds its cognate receptor, activates $\mathrm{NF}-\kappa \mathrm{B}(36-38)$. Therefore, this interaction leads to a vicious cycle of proinflammatory signalling. Inhibition of the NLRP3 inflammasome has been reported to reduce macrophage and neutrophil infiltration into the liver of an MCD-induced NASH model (35). The present study demonstrated that the expression of NLRP3 was inhibited by resveratrol in NASH model mice and by PXR in Hepa1-6 cells. These findings suggested that resveratrol inhibited NLRP3 expression and reduced its proinflammatory action by inducing PXR expression, and subsequently inhibiting $\mathrm{NF}-\kappa \mathrm{B}$ and IL-1 $\beta$ signalling, thereby relieving the inflammatory response in NASH.

IL- 6 is an important member in NF- $\kappa \mathrm{B}$ signalling. In NASH mice, IL-6 expression was increased. Binding of IL-6 to its cellular receptor IL-6R $\alpha$ (CD126) triggers the recruitment of gp130 (CD130), a transmembrane protein important for signal transduction, and results in Janus-activated kinase activation and phosphorylation of transcription factors of the STAT family, particularly STAT3 (39). IL-6 activates STAT3 and STAT3 upregulates IL-6 transcription in turn, forming an autocrine regulatory loop (40). Phosphorylated STAT3 has been reported to upregulate hepatic expression of CD14, a marker of activation of Kupffer cells, playing an important role in inflammation (41). Resveratrol administration can also inhibit activation of the STAT3 pathway, thereby resulting in suppression of Kupffer cell activation in the liver (42). In the present study, resveratrol and PXR reduced IL-6 and STAT3 expression in NASH model mice and Hepa1-6 cells, respectively. Therefore, resveratrol may improve liver inflammation through mmu-miR-599/PXR pathway-mediated inhibition of $\mathrm{NF}-\kappa \mathrm{B} / \mathrm{IL}-6 / \mathrm{STAT} 3$ signalling in the liver.
In conclusion, the present study identified that mmu-miR-599 expression was increased in NASH, and mmu-miR-599 inhibited PXR expression at the transcriptional level and then promoted the expression of inflammatory factors, thus indicating that the mmu-miR-599/PXR pathway may have an important role in the development of NASH. Resveratrol exhibited protective roles in ameliorating hepatic injury in NASH. This effect was mediated by the mmu-miR-599/PXR pathway. Therefore, resveratrol may serve as an effective therapeutic approach for steatohepatitis. However, liver fibrosis was not explored in this study. The effect of resveratrol on NASH-associated liver fibrosis should be verified in our further study.

\section{Acknowledgements}

Not applicable.

\section{Funding}

The present study was supported by the Natural Science Foundation of Hebei Province (grant. no. H2021206140), the Provincial Medical Talents Project funded by Hebei government (2020), the Scientific Research Project of Hebei Provincial Administration of Traditional Chinese Medicine (grant no. 2015027) and the Medical Science Research Project of Hebei Province (grant no. 20190620).

\section{Availability of data and materials}

All data generated or analysed during this study are included in this published article.

\section{Authors' contributions}

RW, YN and LK conceived and designed the study. XA, LH, SZ and LL performed the experiments and collected the data. LK and SZ analysed the data and wrote the manuscript. RW reviewed the manuscript. RW and LK confirm the authenticity of all the raw data. All authors have read and approved the final manuscript.

\section{Ethics approval and consent to participate}

All protocols and procedures were performed following the guidelines of the Hebei Committee for Care and Use of Laboratory Animals and were approved by the Animal Experimentation Ethics Committee of Hebei Medical University (Shijiazhuang, China).

\section{Patient consent for publication}

Not applicable.

\section{Competing interests}

The authors declare that they have no competing interests.

\section{References}

1. Friedman SL, Neuschwander-Tetri BA, Rinella M and Sanyal AJ: Mechanisms of NAFLD development and therapeutic strategies. Nat Med 24: 908-922, 2018. 
2. Eslam M, Valenti L and Romeo S: Genetics and epigenetics of NAFLD and NASH: Clinical impact. J Hepatol 68: 268-279, 2018

3. Ryan MC, Itsiopoulos C, Thodis T, Ward G, Trost N, Hofferberth S, O'Dea K, Desmond PV, Johnson NA and Wilson AM: The Mediterranean diet improves hepatic steatosis and insulin sensitivity in individuals with non-alcoholic fatty liver disease. J Hepatol 59: 138-143, 2013.

4. Baur JA and Sinclair DA: Therapeutic potential of resveratrol: The in vivo evidence. Nat Rev Drug Discov 5: 493-506, 2006.

5. Faghihzadeh F, Adibi P, Rafiei R and Hekmatdoost A: Resveratrol supplementation improves inflammatory biomarkers in patients with nonalcoholic fatty liver disease. Nutr Res 34: 837-843, 2014.

6. Tejada S, Capó X, Mascaró CM, Monserrat-Mesquida M, Quetglas-Llabrés MM, Pons A, Tur JA and Sureda A: Hepatoprotective effects of resveratrol in non-alcoholic fatty live disease. Curr Pharm Des 27: 2558-2570, 2021.

7. Filipowicz W, Bhattacharyya SN and Sonenberg N: Mechanisms of post-transcriptional regulation by microRNAs: Are the answers in sight? Nat Rev Genet 9: 102-114, 2008.

8. Wang Y, Du J, Niu X, Fu N, Wang R, Zhang Y, Zhao S, Sun D and Nan Y: MiR-130a-3p attenuates activation and induces apoptosis of hepatic stellate cells in nonalcoholic fibrosing steatohepatitis by directly targeting TGFBR1 and TGFBR2. Cell Death Dis 8: e2792, 2017.

9. Du J, Niu X, Wang Y, Kong L, Wang R, Zhang Y, Zhao S and Nan Y: MiR-146a-5p suppresses activation and proliferation of hepatic stellate cells in nonalcoholic fibrosing steatohepatitis through directly targeting Wnt1 and Wnt5a. Sci Rep 5: 16163, 2015

10. Wang DP, Tang XZ, Liang QK, Zeng XJ, Yang JB and Xu J: MicroRNA-599 promotes apoptosis and represses proliferation and epithelial-mesenchymal transition of papillary thyroid carcinoma cells via down-regulation of Hey2-depentent Notch signaling pathway. J Cell Physiol 235: 2492-2505, 2020.

11. Zhou JL, Deng S, Fang HS, Du XJ, Peng H and Hu QJ: Circular RNA circANKRD36 regulates Casz1 by targeting miR-599 to prevent osteoarthritis chondrocyte apoptosis and inflammation. J Cell Mol Med 25: 120-131, 2021.

12. Schwabe RF and Luedde T: Apoptosis and necroptosis in the liver: A matter of life and death. Nat Rev Gastroenterol Hepatol Dec 15: 738-752, 2018.

13. Okamura M, Shizu R, Abe T, Kodama S, Hosaka T, Sasaki T and Yoshinari K: PXR functionally interacts with NF- $\kappa$ B and AP-1 to downregulate the inflammation-induced expression of chemokine CXCL2 in mice. Cells 9: E2296, 2020.

14. Gu X, Ke S, Liu D, Sheng T, Thomas PE, Rabson AB, Gallo MA Xie W and Tian Y: Role of NF-kappaB in regulation of PXR-mediated gene expression: A mechanism for the suppression of cytochrome P-450 3A4 by proinflammatory agents. J Biol Chem 281: 17882-17889, 2006 .

15. Du J, Niu X, Wang R, Zhao S, Kong L, Zhang Y and Nan Y: TLR4-dependent signaling pathway modulation: A novel mechanism by which pioglitazone protects against nutritional fibrotic steatohepatitis in mice. Mol Med Rep 13: 2159-2166, 2016.

16. Li S, Zheng X, Zhang X, Yu H, Han B, Lv Y, Liu Y, Wang X and Zhang Z: Exploring the liver fibrosis induced by deltamethrin exposure in quails and elucidating the protective mechanism of resveratrol. Ecotoxicol Environ Saf 207: 111501, 2021.

17. Lv Y, Bing Q, Lv Z, Xue J, Li S, Han B, Yang Q, Wang X and Zhang Z: Imidacloprid-induced liver fibrosis in quails via activation of the TGF- $\beta 1 /$ Smad pathway. Sci Total Environ 705: 135915, 2020

18. Han B, Wang X, Wu P, Jiang H, Yang Q, Li S, Li J and Zhang Z: Pulmonary inflammatory and fibrogenic response induced by graphitized multi-walled carbon nanotube involved in cGAS-STING signaling pathway. J Hazard Mater 417: 125984, 2021.

19. Brunt EM, Janney CG, Di Bisceglie AM, Neuschwander-Tetri BA and Bacon BR: Nonalcoholic steatohepatitis: A proposal for grading and staging the histological lesions. Am J Gastroenterol 94: 2467-2474, 1999.

20. Kleiner DE, Brunt EM, Van Natta M, Behling C, Contos MJ, Cummings OW, Ferrell LD, Liu YC, Torbenson MS, Unalp-Arida A, et al: Design and validation of a histological scoring system for nonalcoholic fatty liver disease. Hepatology 41: $1313-1321,2005$

21. Livak KJ and Schmittgen TD: Analysis of relative gene expression data using real-time quantitative PCR and the 2(-Delta Delta C(T)) method. Methods 25: 402-408, 2001.

22. Zanieri F, Levi A, Montefusco D, Longato L, De Chiara F, Frenguelli L, Omenetti S, Andreola F, Luong TV, Massey V, et al: Exogenous liposomal ceramide-C6 ameliorates lipidomic profile, energy homeostasis, and anti-oxidant systems in NASH. Cells 9: 1237,2020
23. Pilling D, Karhadkar TR and Gomer RH: A CD209 ligand and a sialidase inhibitor differentially modulate adipose tissue and liver macrophage populations and steatosis in mice on the Methionine and Choline-Deficient (MCD) diet. PLoS One 15: $\mathrm{e} 0244762,2020$.

24. Baur JA, Pearson KJ, Price NL, Jamieson HA, Lerin C, Kalra A, Prabhu VV, Allard JS, Lopez-Lluch G, Lewis K, et al: Resveratrol improves health and survival of mice on a high-calorie diet. Nature 444: 337-342, 2006.

25. Li Y, Xu S, Mihaylova MM, Zheng B, Hou X, Jiang B, Park O, Luo Z, Lefai E, Shyy JY, et al: AMPK phosphorylates and inhibits SREBP activity to attenuate hepatic steatosis and atherosclerosis in diet-induced insulin-resistant mice. Cell Metab 13: 376-388, 2011.

26. Shang J, Chen LL, Xiao FX, Sun H, Ding HC and Xiao H: Resveratrol improves non-alcoholic fatty liver disease by activating AMP-activated protein kinase. Acta Pharmacol Sin 29: 698-706, 2008

27. Nan YM, Han F, Kong LB, Zhao SX, Wang RQ, Wu WJ and $\mathrm{Yu} \mathrm{J}$ : Adenovirus-mediated peroxisome proliferator activated receptor gamma overexpression prevents nutritional fibrotic steatohepatitis in mice. Scand J Gastroenterol 46: 358-369, 2011.

28. $\mathrm{Hu} \mathrm{G}, \mathrm{Xu} \mathrm{C}$ and Staudinger JL: Pregnane $\mathrm{X}$ receptor is SUMOylated to repress the inflammatory response. J Pharmacol Exp Ther 335: 342-350, 2010.

29. Mencarelli A, Renga B, Palladino G, Claudio D, Ricci P, Distrutti E, Barbanti M, Baldelli F and Fiorucci S: Inhibition of NF- $\kappa$ B by a PXR-dependent pathway mediates counter-regulatory activities of rifaximin on innate immunity in intestinal epithelial cells. Eur J Pharmacol 668: 317-324, 2011.

30. Zhou C, Tabb MM, Nelson EL, Grün F, Verma S, Sadatrafiei A, Lin M, Mallick S, Forman BM, Thummel KE and Blumberg B: Mutual repression between steroid and xenobiotic receptor and NF-kappaB signaling pathways links xenobiotic metabolism and inflammation. J Clin Investig 116: 2280-2289, 2006

31. Huang K, Mukherjee S, DesMarais V, Albanese JM, Rafti E, Draghi Ii A, Maher LA, Khanna KM, Mani S and Matson AP: Targeting the PXR-TLR4 signaling pathway to reduce intestinal inflammation in an experimental model of necrotizing enterocolitis. Pediatr Res 83: 1031-1040, 2018.

32. Li J, Jiang H, Wu P, Li S, Han B, Yang Q, Wang X, Han B, Deng N, Qu B and Zhang Z: Tox icological effects of deltamethrin on quail cerebrum: Weakened antioxidant defense and enhanced apoptosis. Environ Pollut 286: 117319, 2021

33. Hess J, Angel P and Schorpp-Kistner M: AP-1 subunits: Quarrel and harmony among siblings. J Cell Sci 117: 5965-5973, 2004.

34. Wree A, McGeough MD, Inzaugarat ME, Eguchi A, Schuster S, Johnson CD, Peña CA, Geisler LJ, Papouchado BG, Hoffman HM and Feldstein AE: NLRP3 inflammasome driven liver injury and fibrosis: Roles of IL-17 and TNF in mice. Hepatology 67: 736-749, 2018

35. Mridha AR, Wree A, Robertson AAB, Yeh MM, Johnson CD, Van Rooyen DM, Haczeyni F, Teoh NC, Savard C, Ioannou GN, et al: NLRP3 inflammasome blockade reduces liver inflammation and fibrosis in experimental NASH in mice. J Hepatol 66: 1037-1046, 2017.

36. Masters SL: Specific inflammasomes in complex diseases. Clin Immunol 147: 223-228, 2013.

37. Schroder K and Tschopp J: The inflammasomes. Cell 140: $821-832,2010$

38. Ouyang X, Ghani A and Mehal WZ: Inflammasome biology in fibrogenesis. Biochim Biophys Acta 1832: 979-988, 2013.

39. Rose-John S, Scheller J, Elson G and Jones SA: Interleukin-6 biology is coordinated by membrane-bound and soluble receptors: Role in inflammation and cancer. J Leukoc Biol 80: 227-236, 2006.

40. Grivennikov S and Karin M: Autocrine IL-6 signaling: A key event in tumorigenesis? Cancer Cell 13: 7-9, 2008.

41. Imajo K, Fujita K, Yoneda M, Nozaki Y, Ogawa Y, Shinohara Y, Kato S,MawatariH,Shibata W,Kitani H, etal:Hyperresponsivity to low-dose endotoxin during progression to nonalcoholic steatohepatitis is regulated by leptin-mediated signaling. Cell Metab 16: 44-54, 2012

42. Kessoku T, Imajo K, Honda Y, Kato T, Ogawa Y, Tomeno W, Kato S, Mawatari H, Fujita K, Yoneda M, et al: Resveratrol ameliorates fibrosis and inflammation in a mouse model of nonalcoholic steatohepatitis. Sci Rep 6: 22251, 2016.

This work is licensed under a Creative Commons Attribution-NonCommercial-NoDerivatives 4.0 International (CC BY-NC-ND 4.0) License. 